G. Domenighetti, Sezione Sanitaria, DOS, Bellinzona, Switzerland and faculty of Economics and Social Science, University of Geneva, Switzerland

\title{
Editorial
}

\section{From ethics of ignorance to consumers empowerment}

Medical science and physicians activities are perceived by the public as the "most scientific" forms of scientific activity and research $^{1}$. This perception arises in particular from the mythical and triumphal view of medicine promoted by the media. In fact, practice variations ${ }^{2-3}$, medical uncertainty and clinical disagreement ${ }^{4-7}$, the dissemination of new technologies and practices before or without evaluation ${ }^{1,8,9}$ and the induction of prescribing practices by market related factors ${ }^{10-11}$, are symptoms (i) of the weakness of scientific basis of medicine ${ }^{12}$ and (ii) of superficial diagnostic skills and/or therapeutic management by the medical profession in general and by "cookbook" doctors in particular. These facts are not known by the general public and they could have profound and harmful consequences both for individuals and for society resulting in personal damages, unnecessary hopes or fears for the patient and in waste of ressurces for society ${ }^{1,7-9,13-15}$. Until now doctors have never been on strike for "poor quality" but only for perceived or real "poor gains" or other money related issues ${ }^{16}$.

The dominant "paternalistic" model ${ }^{17}$ of the doctor-patient relationship, especially with frail or low-educated patients, seems to lead to a new one: the "folie à deux" model, well described by Richard Smith ${ }^{1}$, in which patients and doctors play a modern version of Molière's last masterpiece "Le malade imaginaire" ${ }^{18}$. This last model is based on the evidence that about only $10-20$ percent of medical practices are supported, according to the US Congressional Office of Technology Assessment ${ }^{9}$, by randomized controlled trials, what means that $80-90$ percent of medical practices are not supported by solid scientific evidence.
Facing this abundant lack of wisdom, lectures on the "Ethics of ignorance" " should urgently take place in every medical school "to help doctors to become better doctors" 19 and to promote a "healthy skepticism" that ought to be the "in" attitude for intelligent, discriminating physicians ${ }^{20}$.

I wish to argue here that it would be better if that abundant part of uncertainty were shared more often with the patient in the consulting-room. Furthermore a "Healthy Suspicion" regarding the

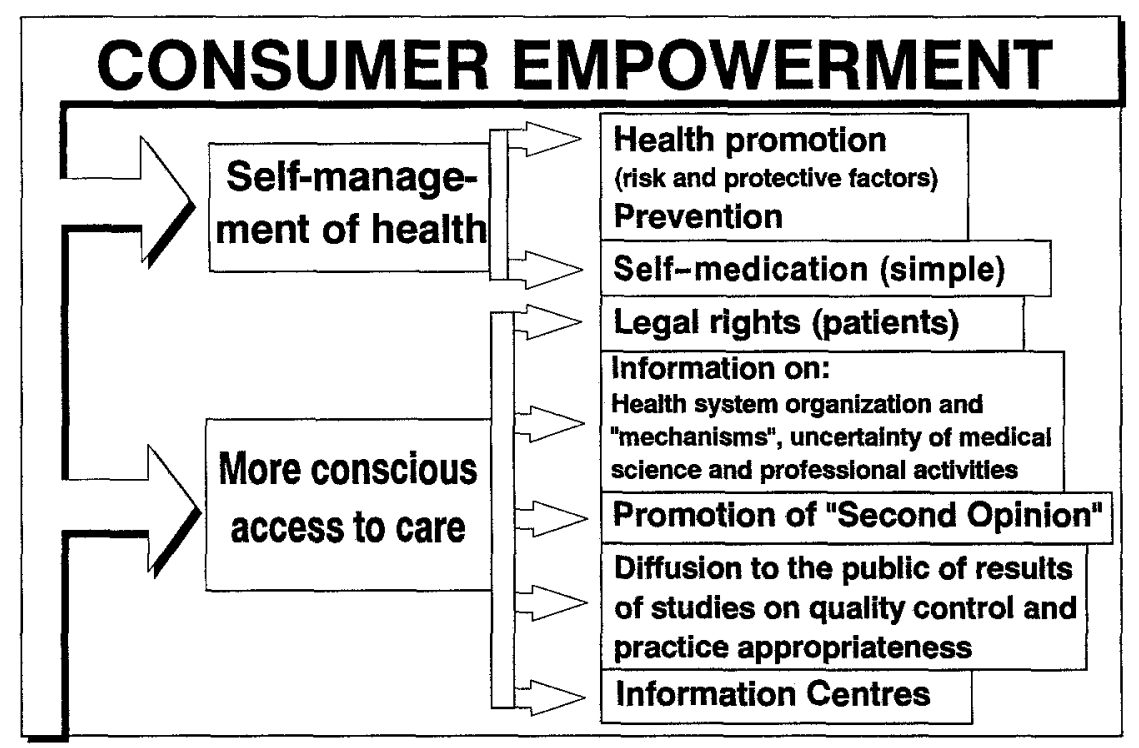


effectiveness and appropriateness of the medical health care system in curing people from most diseases ${ }^{1,21}$ or keeping death at bay could be urgently promoted into the public. A wider recognition of the uncertainty and weakness of medicine is an essential step towards better consumer empowerment, in particular regarding a scientifically based self-management of health ${ }^{22-31}$, the promotion of a more thoughtfull access to medical care ${ }^{32-40}$ and, as a consequence, to a more active role for the patient in his relationship with health professionals. In this way the widely held view that medical practice offers service similar to that of a "car-repair" agency could be modified.

Providing supplementary information to consumers through the input of "transparency" into the health care market can also change demand and professional practices and attitudes, as was observed after a population information campaign on hysterectomy rates ${ }^{41}$. Furthermore the less informed patients have been found to have the highest consumption of common surgical procedures ${ }^{42}$. These findings suggest that as the public becomes more informed demand decreases.

In conclusion, consumer empowerment seems to be a necessary buttress against the important lack of wisdom in medical science and the uncertainty of professional activity and has not to be perceived as an erosion of the public physician's authority but as the foundation of a new partnership to which physicians should, in fact, be enthusiastic contributors.

Consumer empowerment leads to more autonomy and freedom for the individual, be that individual in perceived good or bad health. Furthermore it should be realized that consumer empowerment is in the best interest of health professionals in that it (i) diminishes the frustration encountered ${ }^{43}$ in communicating with patient (ii) helps the patient to determine and choose the best health related values, thus sharing the responsability of choice with him ${ }^{17}$ and finally (iii) it brings the patient's views and experiences with illness back to the center of medical attention ${ }^{44}$.

\section{References}

1 Smith $R$. The ethics of ignorance. J. Med. Ethics 1992; 18:117-118, 134.

2 Wennberger J, Gittelsohn A. Small area variations in health care delivery. Science $1973 ; 182: 1102-1107$.

3 Ham C. Health care variations: assessing the evidence. London: King's Fund Institute, 1988.

4 Wennberger JE, Barnes $B A$, $Z u b k o f f M$. Professional uncertainty and the problem of supplierinduced demand. Soc. Sci. Med. 1982; 16:811-824.

5 Brook RH, Kosekoff JB, Park RE, et al. Diagnosis and treatment of coronary diseases: comparison of doctors' attitudes in the USA and in UK. Lancet 1988; $i: 750-753$.

6 Smith DG, Pekkanem J. Should there be a moratorium on the use of cholesterol lowering drugs? BMJ 1992; 304:431-434.

7 Johansson JR, Adami HO, Andersson $S O$, et al. High 10-years survival and quality of life among patients with early untreated prostatic cancer. JAMA 1992; 267:21912196.

8 Maynard A, Hutton J. Health care reform: the search for the holy grail. Health Economics 1992; $1: 1-3$.

9 Eddy $D M$, Billings $J$. The quality of medical evidence: implications for quality of care. Health Affairs 1988; 1:19-32.

10 Hemenway D, Killen A, Cashman $S B$, et al. Physician's responses to financial incentives. N. Engl. J. Med. 1990; 322:1059-1063.

11 Chren MM, Landefeld CS, Murray TH. Doctors, drug companies and gifts. JAMA 1989; 262:34483451.
12 Smith $R$. Where is the wisdom? The poverty of medical evidence. BMJ 1991; 303:798-799.

13 Black WC, Welch $H G$. Advances in diagnostic imaging and overestimation of diseases prevalence and the benefits of therapy. N. Engl. J. Med. 1993; 17:1237-1243.

14 Harvard Medical Practice Study. Patients, doctors and lawyers: medical injury, malpractice litigations and patient compensation in New York. Report of the State of New York. Boston: Harvard University, 1990.

15 Domenighetti $G$, Casabianca $A$, Barazzoni $F$, Lopipero $P$. Cholesterol screening in children. JAMA 1991; $265: 3249$.

16 Robert Brook statement given at the Conference on "Quality of care", Inselspital, Bern (Switzerland), 22 April 1993.

17 Emanuel EJ, Emanuel LL. Four models of the physician-patient relationship. JAMA 1992; 267: 2221-2226.

18 Molière. Le malade imaginaire. Paris: Edition La Grange et Vinot, 1682 (first edition).

19 Bowen DR. What is quality care? N. Engl. J. Med. 1987; 316:15781580.

20 English TL. Skeptical of skeptics. JAMA 1991; $265: 964$.

21 Bailar JC, Smith EM. Progress against cancer? N. Engl. J. Med. 1986; 314:1226-1232.

22 Manson JE, Tosteson H, Ridker $P M$, Satterfield $S$, et al. The primary prevention of myocardial infarction. N. Engl. J. Med. 1992; 21:1406-1416.

23 Henderson BE, Ross RK, Pike $M C$. Towards the primary prevention of cancer. Science 1991; 254:11311138.

24 Shekelle RB, Lepper $M$, Liu S, Maliza $C$, et al. Dietary vitamin A intake and risk of cancer in Western Electric Study. Lancet 1981; ii: 1185-1190.

25 Willet WC, Stampfer MJ, Colditz $G A$, Rosner BA, Speizer FE. Relation of meat, fat and fiber intake to the risk of colon cancer in a pros- 
pective study among women. N. Engl. J. Med. 1990; 323:16641672.

26 Rimm EB, Stampfer MJ, Ascherio $A$, Giovannucci $E$, Colditz $G A$, Willet $W C$. Vitamin E consumption and the risk of coronary heart disease in men. N. Engl. J. Med. 1993; 328:1450-1456.

27 Rimm EB, Giovannucci EL, Willet $W C$, et al. A prospective study of alcohol consumption and risk of coronary disease in men. Lancet 1991; 338:464-468.

28 Steering Commitee of the Physicians' Health Study Research Group. Final report on the aspirin component of the ongoing Physicians' Health Study. N. Engl. J. Med. 1989; 321:129-135.

29 ISIS-2 Collaborative Group. Randomized trial of intravenous streptokinase, oral aspirine, both, or neither among 17187 cases of suspected acute myocardial infarction: ISIS-2. Lancet 1988; $i i$ : $349-360$.

30 Logan RFA, Little J, Hawtin PG, Hardcastle JD. Effect of aspirin and nonsteroidal anti-inflammatory drugs on colorectal adenomas: case-control study of subjects participating in the Nottingham faecal occult blood screening programme. BMJ 1993; 307: 285 289.

31 Herlitz $J$, et al. Follow-up of 1-year media campaign on delay times and ambulance use in suspected acute myocardial infarction. Eur. Heart J. 1992; 13:171-177.

32 Braverman J. The consumer's book of health. Philadelphia: The Saunders Press, 1982.

33 Grafe WR. The second opinion program. In: Selbann KH, Uberla KK, eds. Quality assessment of medical care. Gerlingen: Bleicher Verlag, 1982; 125-135.

34 Inlander CB, Pavalon EI. Your medical rights: how to become an empowered consumer. Boston: Little Brown \& Company, 1990.

35 Inlander $C B .150$ ways to be a savy medical consumer. Allentown: People's Medical Society, 1992.
36 Inlander $C B$, Brisco $P$. The consumer's guide to medical lingo. Allentown: People's Medical Society, 1992.

37 Inlander $C B$, Weiner $E$. Take this book to the hospital with you. Reading, MA: Addison-Wesley, 1991.

38 Maleskey $G$, Inlander $C B$. Take this book to the gynecologist with you: a consumer's guide to women's health. Reading, MA: AddisonWesley, 1991.

39 Hendler SS. The doctor's vitamin and mineral encyclopedia. New York: Simon \& Schuster, 1990.

40 Arnot $R$. The best medicine: how to choose the top doctors, the top hospitals and the top treatments. Reading, MA: Addison-Wesley, 1992.

41 Domenighetti $G$, Luraschi P, Casabianca $A, G$ utzwiller $F$, Spinelli $A$, Pedrinis E, Repetto $F$. Effect of information campaign by the massmedia on hysterectomy rates. Lancet 1988; $i i: 1470-1473$.

42 Domenighetti G, Gutzwiller F, Martinoli $S$, Casabianca $A$. Revisiting the physician-patient as an informed consumer of surgical services. Int. J. Technol. Assess. Health Care 1993; 4:505-513.

43 Levinson W, Stiles WB, Invi TS, Engle $R$. Physician frustration in communicating with patients. Med. Care 1993; 4:285-295.

44 Reiser SJ. The era of the patient. Using the experience of illness in shaping the mission of health care. JAMA 1993; 269:1012-1017.

\section{Address for correspondence}

G. Domenighetti
Sezione Sanitaria
DOS

CH-6500 Bellinzona/Switzerland 